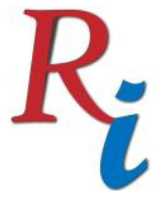

Asia Proceedings of Social Sciences

(APSS)

www.readersinsight.net/APSS

\title{
AFFORDABLE HOUSING IN NIGERIA USING CRITICAL SUCCESS FACTORS OF PUBLIC PRIVATE PARTNERSHIP \\ Yahaya Ahmed*
}

Faculty of Built Environment and surveying

Universiti Teknologi Malaysia, 81310 Skudai, Johor

Malaysia

\section{Ibrahim Atan Bin Sipan}

Faculty of Built Environment and surveying

Universiti Teknologi Malaysia, 81310 Skudai, Johor

Malaysia

*Corrosponding author's Email: yahmednas1@gmail.com

Peer-review under responsibility of $3^{\text {rd }}$ Asia International Multidisciplanry Conference 2019 editorial board (http://www.utm.my/asia/our-team/) (C) 2019 Published by Readers Insight Publisher, lat 306 Savoy Residencia, Block 3 F11/1,44000 Islamabad. Pakistan, info@readersinsight.net This is an open access article under the CC BY-NC-ND license (http://creativecommons.org/licenses/by-nc-nd/4.0/). 


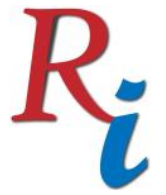

Asia Proceedings of Social Sciences

(APSS)

www.readersinsight.net/APSS

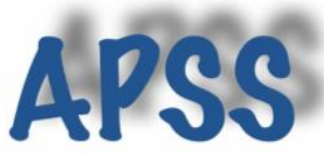

\section{Rese a r ch H i g h I igh t s}

Housing provision has become a global problem. According to UN, housing is lacking in virtually all society among the developing countries due to population growth and urbanization (UN-HABITAT, 2006). However, Public private partnership was introduce by the Nigerian Government as an option to end the current crisis of housing shortage and affordable housing in the country(Lagos State Government, 2008). This study relies on interview with PPP expert to build up questionnaire survey on success factors of PPP for affordable housing in Nigeria. The findings reveal the relevance success factors of PPP for affordable housing provision in Nigeria and also suggest a way forward for best implementation PPP for affordable housing in Nigeria.

\section{Graphical Abstract}

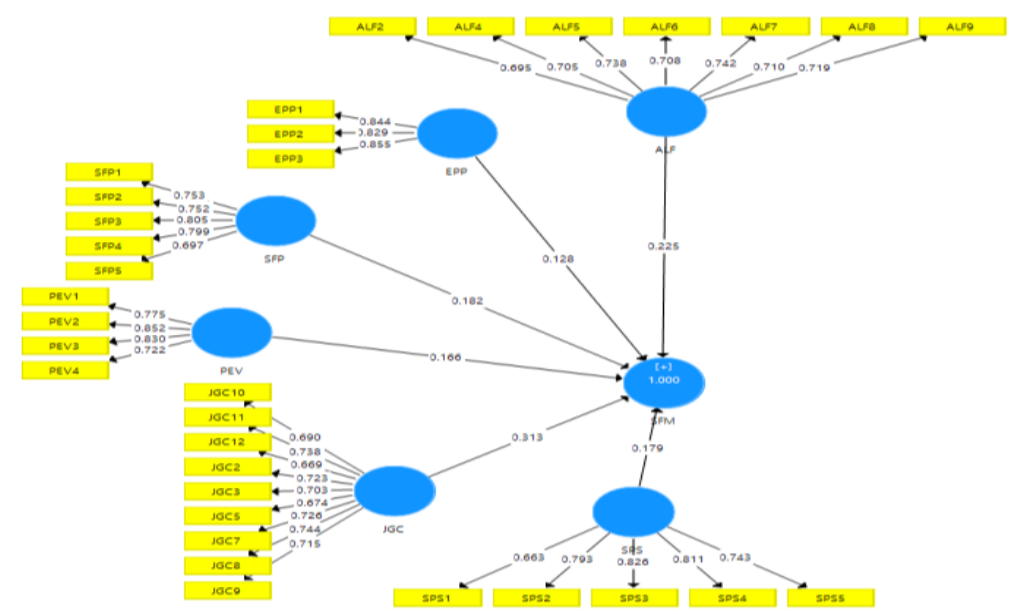

Fig. 1 Critical Success Factors Structural Model (SFM)

\section{Research Objectives}

This study aim to identified factors that can facilitate the building, performance and success of PPP as an instrument for affordable housing provision in the study area. A comprehensive literature review discovery has revealed the need for affordable housing provision for emerging lower classes, and also shows that this cannot be fulfilled by using current approaches due to poor understanding of problems. However, developing a theoretical background that critical success factors are localized based on the contextual context of administrative territories, this study uses SEM to determine the success of PPP affordable housing in Nigeria ( Kavishe and Chileshe, 2018). The results reveals that there are Six significant component success factors of PPP for affordable housing provision in Nigeria, this include; adequate legal framework, effective procurement process, sound financial package, project economic viability, judicial government control, \& strong private sector. Based on the findings, this chapter proposes a framework for determining the success of PPP's affordable housing provision and to drawing on policy implications for improving PPP affordable housing provision in Nigeria. It therefore suggests that government should strongly provide a policies to support the success of PPP for affordable housing provision in Abuja, and also provide a means of subsidy to promote PPP toward provision of affordable housing. 


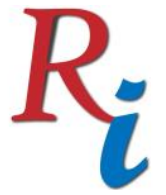

Asia Proceedings of Social Sciences

(APSS)

www.readersinsight.net/APSS

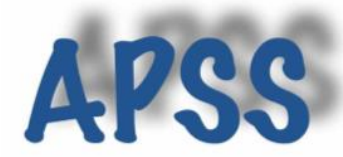

\section{Methodology}

The study uses sequential mixing methods, the purpose of design successively sequential design methods involves first qualitative data collection procedures to explore phenomena, and then collect quantitative data to clarify existing relationships in qualitative data (Creswell, 2003).

This study uses focus group discussions with PPP experts and identifies relevant success factors for the delivery of PPP affordable housing in Nigeria. Professional background respondents for group interviews have identified their knowledge of PPP projects. Pioneer surveys were conducted to study the effectiveness of research instruments using the Cronbach Alpha and Kaiser-Meyer-Olkin statistical methods. This instrument was found to be reliable and valid as a preparation for a questionnaire survey.

As Hurst et. al., (2015). states, questionnaire items should be obtained from literature review and validated by focus group interviews and tested before using them in full-scale data collection. The questionnaire was distributed to stakeholders of public and private developers who participated in the provision of PPPs in Abuja Nigeria. A total of 350 questionnaires were randomly assigned to target audience (Stakeholders from both public and private sector officials) who participated in PPP housing and property developers) at FCT where 254 questionnaires were returned. Data from questionnaire were analyzed using PPSS software for factor analysis and smart PLS used to analyze data.

\section{Results}

Effective procurement process has a composite reliability value of (0.880), Sound Financial Package also has a strong composite reliability value of (0.901), Project Economic Viability also has a strong composite reliability value of $(0.874)$ and Strong Private sector has composite reliability value of (0.878). Therefore, the composite reliability value for all the construct under the critical success factors shows that all the construct have a strong acceptable value that is higher than the minimum acceptable value of 0.6 (Safiih et. Al., 2016).

The reflective measured model after establishing the composite reliability value, the AVE were shown as follows; Adequate Legal Framework (0.514), Effective procurement process (0.710), Sound Financial Package (0.503), Project Economic Viability (0.634), Judicial Government control(0.581), and Strong Private sector (0.592), this indicate that convergent validity has been accepted (Civelek,2018; Hair et al, 2014).

The discriminant validity values for the reflective constructs with all constructs HTMT value below 0.90. Therefore, discriminant validity has been accepted. Therefore, the composite reliability, convergent validity and the discriminant validity test show that the success factors of public private partnership has a significant relationship with affordable housing in Abuja, this show that without the success factors public private partnership affordable housing cannot be provided in Abuja Nigeria

\section{Findings}

Findings of the study reveals that, PPPs is facing a tremendous problems of housing provision in the study area, this include the acquisition and access to land, poor implementation of housing policies, adequate housing finance, difficulty of accessibility to mortgage facilities and land titles, Massive rural urban migration and cost recovery among others. Just like the previous public housing delivery strategy, this approach is skewed towards providing housing for high- and middle-income earners in Abuja and other part of Nigerian (Makinde 2014). However, the provision of affordable housing has not yet been reached in the study area. The 


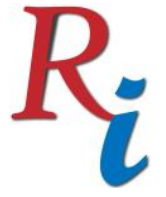

\section{Asia Proceedings of Social Sciences (APSS) \\ www.readersinsight.net/APSS}

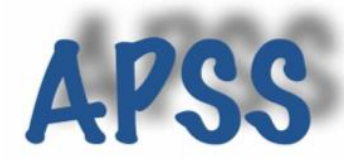

point that there is no consensus on the State Policy on PPP in housing in Nigeria is anxiety (Olofa S. and Nwosu A. 2015). Since PPP for affordable housing in Abuja Nigeria is unclear. Hence, it shows that PPP practices for affordable housing are then regarded as governance controls as the main component of affordable housing. It is therefore recommended that a good policy framework for the implementation of other variants of PPPs in meeting the affordable housing in Nigeria should be consider on the constituent parameter of affordable housing (Muhammad and Johar 2018). First of all, it will wipe out all the underlying constraints that cannot define local government authorities and grassroots organizations in PPP for affordable housing, and then provide the needs of different socioeconomic groups in the country's sub sector of housing in Nigeria. Land allocation and government rights documents at premium cost add to the cost of housing provided by PPP (Oni-Jimoh et. Al., 2018).

\section{Acknowledgement}

The author is grateful to Almighty Allah for giving me ability to write this paper. A special honour to my supervisor Ass. Prof Dr. Ibrahim Atan Bin Sipan of Department of Property Management, Faculty of Built Environment and surveying, Universiti Teknologi Malaysia, 81310 Skudai, Johor, Malaysia for taking his time to share his knowledge of research with me and giving me a full support to carryout my research I want to thank organization and TETFund for an intervention and support toward my study in Malaysia. I want to thank the UTM for given me the opportunity to be her research student of her greet institution of learning, i say thank you UTM.

\section{References}

Civelek M. E., 2018. Comparison of Covariance-Based and Partial Least Square Structural Equation Modeling Methods under Non-Normal Distribution and Small Sample Size Limitations.Eurasian Econometrics, Statistics \& Emprical Economics Journal 2018 Volume:10 S: 39- 50 .

Creswell, J. W., (2003). Research Design: Quantitative Qualitattive and Mixed methods research designs. Handbook of mixed methods in social and behavioral research, 209-240.

Hair et al, 2014. Partial least squares structural equation modeling (PLS-SEM) An emerging tool in business research. European Business Review Vol. 26 No. 2, 2014 pp. 106-121.

Hurst S., Arulogun O. S., Owolabi A. O., Akinyemi R., Uvere E. Warth S. andOvbiagele B. 2015. Pretesting Qualitative Data Collection Procedures to Facilitate Methodological Adherence and Team Building in Nigeria. Int J Qual Methods. 2015 ; 14: 53-64

Lagos State Government (2008) Lagos State Government PPP initiatives, PPP Brochure (Ikeja: Ministry Of Finance). Available at http://www.lagostate.gov.ng (accessed 14 May 2018).

Muhammad Z., and Johar F. 2018. Coping with Challenges of Public-Private Partnership (PPP) for Housing Delivery in Nigeria. International Journal of Engineering \& Technology, 7 (2.29) (2018) 1097-1101.

Neema Kavishe, Nicholas Chileshe, (2018) "Critical success factors in public-private partnerships (PPPs) on affordable housing schemes delivery in Tanzania: A qualitative study", Journal of Facilities Management, https://doi.org/10.1108/JFM-05-2018-0033

Olofa S. and Nwosu A. 2015. Investigating the Problems Associated with Publicprivate Partnership in the Process of Housing Delivery in Nigeria. International Journal of Education and Research Vol. 3 No. 1 January 2015.

Olusola Oladapo Makinde 2014. Housing delivery system, need and demand Environ Dev Sustain (2014) 16:4969 DOI 10.1007/s10668-013-9474-9

Oni-Jimoh T, Liyanage C, Oyebanji A and Gerges M, 2018 Urbanization and Meeting the Need for Affordable Housing in Nigeria. file://C:/Users/DELL/Downloads/62021.pdf

Safiih m., L1* and Nor Azreen M. A 2016. Confirmatory Factor Analysis Approach: A Case Study of Mathematics Students' Achievement in TIMSS. Malaysian Journal of Mathematical Sciences 10(S) March : 41- 51 (2016). http://einspem.upm.edu.my/journal

UN-HABITAT (2006). Public-Private Partnerships in enabling shelter strategies. Nairobi: United 